\title{
No correlation between the diversity and productivity of assemblages: evidence from the phytophage and predator assemblages in various cotton agroecosystems
}

\author{
GAO Feng ${ }^{1,2}$, MEN XingYuan ${ }^{3} \&$ GE Feng ${ }^{2 *}$ \\ ${ }^{1}$ College of Agriculture and Biotechnology, China Agricultural University, Beijing 100193, China; \\ ${ }^{2}$ State Key Laboratory of Integrated Management of Pest Insects and Rodents, Institute of Zoology, Chinese Academy of Sciences, Beijing \\ 100101, China; \\ ${ }^{3}$ Institute of Plant Protection, Shandong Academy of Agricultural Sciences, Jinan 250100, China
}

Received March 6, 2014; accepted June 16, 2014; published online August 15, 2014

\begin{abstract}
Biodiversity research has shown that primary productivity increases with plant species number, especially in many experimental grassland systems. Here, we assessed the correlation between productivity and diversity of phytophages and natural enemy assemblages associated with planting date and intercropping in four cotton agroecosystems. Twenty-one pairs of data were used to determine Pearson correlations between species richness, total number of individuals, diversity indices and productivity for each assemblage every five days from 5 June to 15 September 2012 . At the same trophic level, the productivity exhibited a significant positive correlation with species richness of the phytophage or predator assemblage. A significant correlation was found between productivity and total number of individuals in most cotton fields. However, no significant correlations were observed between productivity and diversity indices (including indices of energy flow diversity and numerical diversity) in most cotton fields for either the phytophage or the predator assemblages. Species richness of phytophage assemblage and total individual numbers were significantly correlated with primary productivity. Also, species richness of natural enemy assemblage and total number of individuals correlated with phytophage assemblage productivity. A negative but not significant correlation occurred between the indices of numerical diversity and energy flow diversity and lower trophic-level productivity in the cotton-phytophage and phytophage-predator assemblages for most intercropped cotton agroecosystems. Our results clearly showed that there were no correlations between diversity indices and productivity within the same or lower trophic levels within the phytophage and predator assemblages in cotton agroecosystems, and inter-cropped cotton fields had a stronger ability to support the natural enemy assemblage and potentially to reduce phytophages.
\end{abstract}

correlation, productivity, diversity, cotton agroecosystem, insect assemblage

Citation: Gao F, Men XY, Ge F. No correlation between the diversity and productivity of assemblages: evidence from the phytophage and predator assemblages in various cotton agroecosystems. Sci China Life Sci, 2014, 57: 936-943, doi: 10.1007/s11427-014-4733-z

In the past decade, significant progress has been made in understanding the role of biodiversity in ecosystem functioning $[1,2]$. There appears to be the consensus that diversity of plant species is positively correlated with productivity [3-5]. Some researchers believe that it is the number and

*Corresponding author (email: gef@ioz.ac.cn) types of species that influence productivity, which has been the subject of a series of field and laboratory experiments $[3,6]$. These experiments have engendered a lively debate $[7,8]$ that has yet to be resolved. Later studies have reported positive, negative, or U-shaped response patterns between species richness and productivity [9-12].

Understanding the diversity and productivity relationship 
will have significant implications for how we manage biodiversity for ecosystem services. For example, to effectively manage natural enemy diversity for pest control, it is essential to know whether it is better to increase the abundance of the single most effective natural enemy or to augment natural enemy diversity in general [13]. However, current ideas about the relationship between diversity and productivity often focus on plant assemblages, where net primary production is the obvious measure of productivity using relatively pristine systems or experimental mesocosms that approximate natural systems [14-16]. Less attention has been directed to understand relationships between productivity at one trophic level and diversity at the next higher trophic level. Little attention has also been paid to how richness and productivity are related in agroecosystems, which are far from pristine due to a variety of anthropogenic influences $[17,18]$. Moreover, the importance of diversity within higher trophic levels for prey suppression and trophic cascades has been explored only recently and evidence is emerging that changes in natural enemy diversity can, in fact, influence the functioning of ecosystems $[19,20]$, although complementarity and selection effects occur in both animals and plants, few studies have conclusively documented the mechanisms mediating diversity effects [2]. To our knowledge, few studies have examined more complicated ecosystems with several trophic levels, like those that occur in crop-insect pest-natural enemy assemblages [18,21].

Cotton is an important crop around the world. Over the past half-century, many agricultural practices that influence diversity and species richness of an insect assemblage have been studied. Maximizing the impact of natural enemies already present in the cotton agroecosystem could reduce the need for chemical inputs to manage pests [22]. Intercropping and other multiple cropping practices are becoming common in the Southeastern United States, mostly as double cropping of winter wheat and summer soybean [23]. In the Midwestern United States, the combination of soybean and corn in strip intercropping has been used as an economic alternative for monocultures. Additionally, delayed uniform planting, where most cotton is planted after mid-May to delay the appearance of cotton squares until early July, has become an important and widely accepted management strategy in Texas, United States [24,25]. In Northern China, intercropped cotton agroecosystems and mono cotton agroecosystems are very common. The effects of intercropping with wheat or of different planting dates on the physiology and yield of cotton have been extensively studied [26,27]. However, the relationship between crop diversity and productivity and key insect pests and natural enemies in different cotton agroecosystems remains unclear.

In this study, we examined the correlation between productivity and diversity among the three trophic levels associated with planting date and intercropping in four types of cotton agroecosystems using ecological energetics. In particular, we focus on two questions: (i) Is there a correla- tion between productivity and diversity among the three trophic levels in cotton agroecosystems? (ii) Do intercrop and planting date affect the productivity of cotton, insect pests and natural enemies under the condition of no chemical control in Northern China?

\section{Materials and methods}

\subsection{Study area}

This study was conducted in Raoyang County, Hebei Province of Northern China $\left(25^{\circ} \mathrm{N}, 112^{\circ} \mathrm{E}\right)$. The region has a seasonal cumulative temperature of about $3500^{\circ} \mathrm{C}$ above $15^{\circ} \mathrm{C}$ and receives $500-600 \mathrm{~mm}$ of rainfall annually. The soil type is a very fine sandy loam (20\%-22\% clay). Soil organic matter and total $\mathrm{N}, \mathrm{P}$, and $\mathrm{K}$ are about $0.845 \%$, $10.5 \%, 10.8 \%$, and $17.7 \%$, respectively.

The experimental design was arranged as randomised complete blocks with three replications (plots) for each treatment. Each plot was about $400 \mathrm{~m}^{2}$, consisted of 10 rows of cotton, variety Shimian No.11, row spacing was $1 \mathrm{~m}$ and row length was $40 \mathrm{~m}$. The area of these four cotton agroecosystems for this experiment was about $4800 \mathrm{~m}^{2}$. The four cotton agroecosystems for this experiment were as follows: mono cotton seeded on April 27, mono cotton seeded on May 15, wheat-cotton intercrop seeded on April 27, and wheat-cotton intercrop on May 15. The cotton was seeded in 2012 and the wheat was seeded on 1 October 2011 in the middle three rows within the 10-row cotton plots. Wheat and cotton were harvested on June 10 and October 5 in 2012, respectively. Irrigation was applied as needed in the soil. The agronomic manipulations were the same in each plot. No pesticides were applied to any plots during these experiments. Three rows of cotton with the same variety used in the current study were planted in each plot as protect zone.

\subsection{Arthropod sampling}

Five $1-\mathrm{m}^{2}$ sampling sites, each consisting of six cotton plants, were selected randomly in each plot. Numbers of sedentary arthropods (except cotton aphids) were counted visually on the plants at each site every five days from 5 June to 15 September 2012 ( $n=21)$. Flying arthropods were sampled with five sweeps using a $38-\mathrm{cm}$ diameter sweep-net near each sampling site in each plot. Arthropods collected by sweep-net were taken to the laboratory for species identification. The total number of arthropods from sweep nets was also counted. Five plants were randomly selected in each plot for sampling of aphids. The number of aphids was counted on three leaves taken from three different positions within the plant canopy as described by Hardee et al. [28]. Position 1 was the fourth fully expanded leaf below the terminal, position 2 was the first main stem green leaf about one-third the distance of plant height below the terminal, and position 3 was the first main stem green leaf above the first fruiting branch at the base of the plant. The 
arthropod complex was separated into species and classified as phytophages, predators, and parasitoids in each plot on each sampling date.

\subsection{Individual biomass, caloric value and respiratory rate}

The phytophages and natural enemies collected from the cotton plots were killed with ethyl acetate and dried for $48 \mathrm{~h}$ at $60^{\circ} \mathrm{C}$. An automatic electrobalance (R200D, Sartorius $\mathrm{GmbH}$, Germany) was used to obtain dry weight as biomass (mg/individual) for each sample. The caloric value $\left(\mathrm{J} \mathrm{mg}^{-1}\right)$ of each sample was determined with a Bomb calorimeter (PARR 1281, Parr Instrument Company, USA) from combustion of the sample. The energy content of all samples from each trophic classification was recorded separately for each of the three replications. Measurements of $\mathrm{O}_{2}$ consumption rate of the phytophages and natural enemies were made in a Gilson single valve differential respirometer (1GRP-14, Gilson Medical Electronics, France) with a water bath controlled at $25 \pm 0.2^{\circ} \mathrm{C}$ [18]. Ten percent $\mathrm{KOH}$ was used as a $\mathrm{CO}_{2}$ absorbent in the centercentre well of the flasks. Readings were taken every $5 \mathrm{~min}$ for $15 \mathrm{~min}$, and the mean value was used in calculations.

\subsection{Arthropod assemblage productivity and respira- tion capacity}

Based on the net ecological efficiency $(\alpha)$ [29], individual biomass, caloric value, and respiratory rate, the index of arthropod assemblage biomass, respiration capacity $(R)$, and assemblage productivity $(P)$ were estimated by combining the numbers and development stages of each species within each of the four cotton production systems for each sampling date. The coefficient $b=2.58$ was used to correct laboratory values for field conditions [30] to minimize error in estimated field assemblage respiration. Temperature data were taken from a weather station located $1.8 \mathrm{~km}$ distance from our experimental field.

\subsection{Primary productivity in fields}

Five $1-\mathrm{m}^{2}$ of samples of cotton or wheat and associated litter were collected randomly from each plot every five days in $2004(n=21)$ to estimate primary production. Materials were dried for $48 \mathrm{~h}$ at $60^{\circ} \mathrm{C}$, and weight and caloric values were determined as described previously for arthropods. The plant respiration loss was determined according to Thormley [31], and the method of Gao et al. [18] was used to calculate the gross productivity $\left(P_{0}\right)$ of the primary producer (cotton or wheat plant) per unit area $\left(\mathrm{J} \mathrm{m}^{-2}\right)$.

\subsection{Assemblage diversity index}

The Shannon-Weaver diversity index $(H N)$ [32] and diver- sity index for energy flow $(H E)$, which was deduced from the Shannon-Weaver diversity index [18], were used for analysing assemblage diversity.

\subsection{Data analysis}

All the data were analysed using SPSS for Windows, Version 12.0 (SPSS, USA). We analyzed productivity and assimilation of three assemblages using ANOVA method along with one-tailed Fisher's least significant difference (LSD) test at $P<0.05$. Twenty-one pairs of data were used to determine Pearson correlations between species richness $(S)$, total individual numbers $(N)$, diversity indices $(H N)$, energy flow $(H E)$, and productivity $(P)$ for each assemblage every five days from 5 June to 15 September 2012. Correlations were considered significant at $P<0.05$ and at $P<0.01$.

\section{Results}

2.1 Productivity and assimilation of the phytophage and natural enemy assemblages in cotton agroecosystems

\subsubsection{Phytophage assemblage}

Phytophage productivity varied from 106 to $439 \mathrm{~kJ} \mathrm{~m}^{-2} \mathrm{a}^{-1}$ (Figure 1A), and assimilation varied from 221 to $1044 \mathrm{~kJ}$ $\mathrm{m}^{-2} \mathrm{a}^{-1}$ (Figure 2A) in the four cotton agroecosystems, respectively. Significantly higher productivity and assimilation of phytophages were found in late-planted (May 15) monoculture cotton compared to the other three agroecosystems.

\subsubsection{Predator assemblage}

Productivity and assimilation of predators in the four cotton agroecosystems ranged from 41 to $51 \mathrm{~kJ} \mathrm{~m}^{-2} \mathrm{a}^{-1}$ (Figure 1B) and from 59 to $78 \mathrm{~kJ} \mathrm{~m}^{-2} \mathrm{a}^{-1}$ (Figure 2B), respectively. No significant differences in productivity or assimilation of predators were found among the four agroecosystems.

\subsubsection{Parasitoid assemblage}

Parasitoid productivity ranged from 6 to $8 \mathrm{~kJ} \mathrm{~m}^{-2} \mathrm{a}^{-1}$ (Figure 1C) and assimilation from 9 to $12 \mathrm{~kJ} \mathrm{~m}^{-2} \mathrm{a}^{-1}$ (Figure 2C) in the four cotton agroecosystems, and these values were much lower than those observed from phytophages and predators. The lowest parasitoid productivity and assimilation occurred in monoculture late-planted cotton (May 15).

2.2 Correlation between diversity and productivity in phytophage, predator, and parasitoid assemblages in cotton agroecosystems

\subsubsection{Phytophage assemblage}

The productivity of phytophages correlated significantly 



Figure 1 The productivity $(\mathrm{Mean} \pm \mathrm{SE})$ of the phytophage and natural enemy assemblages in four types of cotton agroecosystems $\left(\mathrm{kJ} \mathrm{m}^{-2} \mathrm{a}^{-1}\right)$. The different letters above the four bars in each of the three panels indicate significant differences between the four mean values at $P<0.05$ level by LSD test. 4-27, plants seeded on April 27; 5-15, plants seeded on May 15.

with species richness $(P<0.01)$ in all cotton systems exceptmonoculture cotton seeded on April 27 (Table 1). Moreover, phytophage productivity correlated with total numbers $(P<0.01)$ in all cotton production systems. However, phytophage productivity did not correlate significantly with diversity indices or diversity indices of energy flow, except in the cotton-wheat intercrop seeded on May 15, in which diversity indices correlated strongly with productivity $(P=0.0231)$. Interestingly, diversity indices of energy flow for phytophages displayed negative correlations with productivity in three agroecosystems, although these correlations were not significant.

\subsubsection{Predator assemblage}

Species richness and total individual number of predators significantly correlated $(P=0.0108)$ with productivity in all cotton agroecosystems except cotton plots planted on April
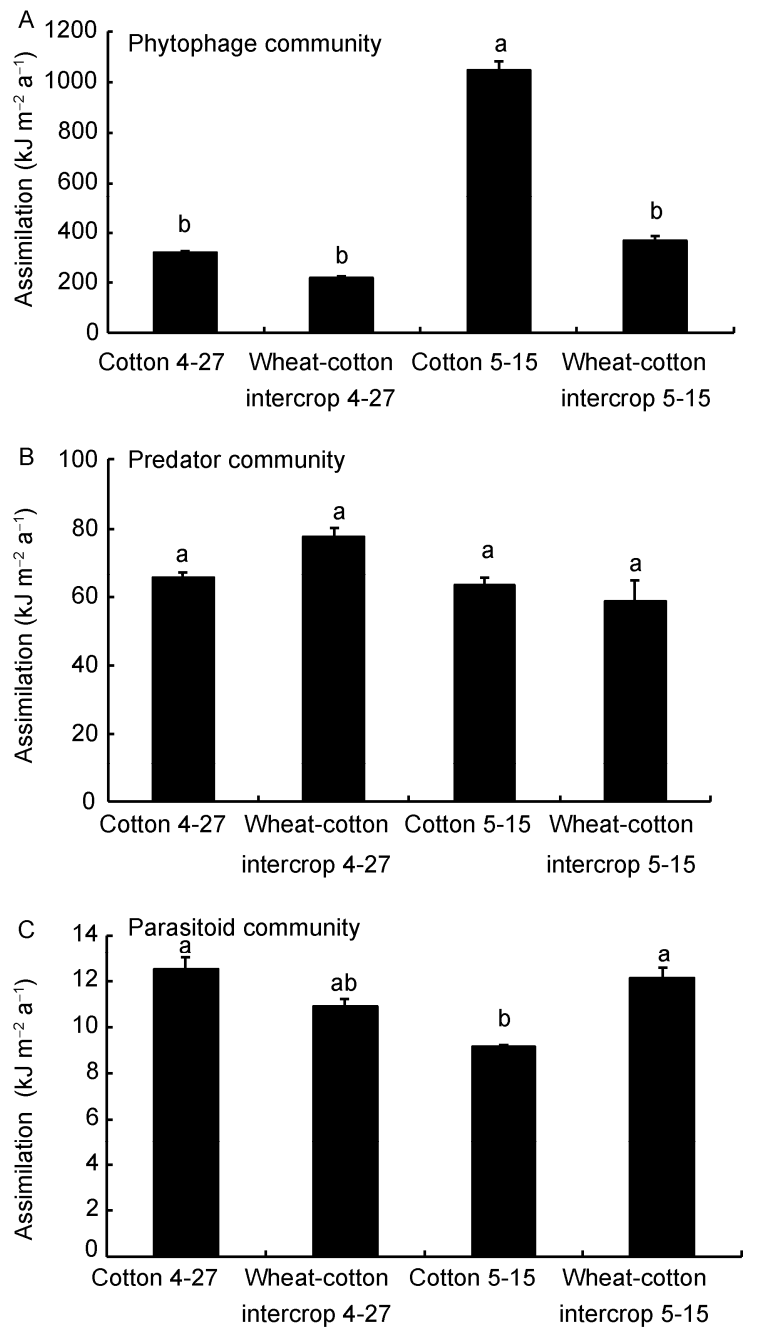

Figure 2 The assimilation (Mean \pm SE) of the phytophage and natural enemy assemblages in four types of cotton agroecosystems $\left(\mathrm{kJ} \mathrm{m}^{-2} \mathrm{a}^{-1}\right)$. The different letters above the four bars in each of the three panels indicate significant differences between the four mean values at $P<0.05$ level by LSD test. 4-27, plants seeded on April 27; 5-15, plants seeded on May 15.

27. No correlation was found between the number diversity indices or diversity indices of energy flow for the predator assemblage with productivity in the four cotton agroecosystems (Table 1).

\subsubsection{Parasitoid assemblage}

Parasitoid productivity showed a notable positive correlation with total individual number of parasitoids in all cotton production systems. Also, a significant correlation was found between species richness and productivity in the mono cultural cotton agroecosystems but not in the intercropped agroecosystems. The correlation between the diversity indices for energy flow and productivity was significant in all plots except for cotton-wheat intercrop planted on May 15. Significant correlations were also found between the number diversity indices and productivity in the plots seeded on April 27 (Table 1). 
Table 1 Correlations between the diversity index and productivity of the phytophage, predator, and parasitoid assemblage in four types of cotton agroecosystems $(\mathrm{d} f=20)^{\mathrm{a})}$

\begin{tabular}{|c|c|c|c|c|c|c|}
\hline Assemblage & Seed time & Types of agroecosystem & $P-S$ & $P-N$ & $P-H E$ & $P-H N$ \\
\hline \multirow{4}{*}{ Phytophage } & April 27 & Cotton & 0.169 & $0.829^{* *}$ & 0.263 & 0.168 \\
\hline & April 27 & Cotton-wheat intercrop & $0.636^{* *}$ & $0.796^{* *}$ & -0.194 & 0.052 \\
\hline & May 15 & Cotton & $0.554^{* *}$ & $0.694^{* *}$ & -0.232 & -0.104 \\
\hline & May 15 & Cotton-wheat intercrop & $0.573^{* *}$ & $0.776^{* *}$ & -0.077 & $0.497 *$ \\
\hline \multirow{3}{*}{ Predator } & April 27 & Cotton & 0.050 & 0.333 & 0.238 & 0.009 \\
\hline & April 27 & Cotton-wheat intercrop & $0.743^{\text {*** }}$ & $0.919^{* *}$ & -0.212 & -0.293 \\
\hline & May 15 & Cotton-wheat intercrop & $0.676^{* *}$ & $0.557^{*}$ & 0.151 & -0.085 \\
\hline \multirow{4}{*}{ Parasitoid } & April 27 & Cotton & $0.524^{*}$ & $0.782^{* *}$ & $0.778^{* *}$ & $0.772^{* *}$ \\
\hline & April 27 & Cotton-wheat intercrop & 0.381 & $0.992_{* *}$ & $0.857^{* *}$ & $0.838^{* *}$ \\
\hline & May 15 & Cotton & $0.506^{*}$ & $0.944^{* *}$ & $0.529^{*}$ & 0.130 \\
\hline & May 15 & Cotton-wheat intercrop & 0.152 & $0.894^{* *}$ & 0.213 & 0.120 \\
\hline
\end{tabular}

a) $P$, the productivity; $S$, species; $N$, total individual numbers; $H E$, diversity indices for assemblage energy flow; $H N$, diversity indices for assemblage numbers. * and $* *$ indicate significant correlation at $P<0.05$ and $P<0.01$, respectively.

\subsection{Correlation between the assemblage structure in- dex and lower assemblage productivity in the four cot- ton agroecosystems}

\subsubsection{Structure index of phytophage assemblage and crop primary productivity}

There was a significant correlation $(P<0.01)$ between species richness of arthropod pests and primary productivity in the cotton-wheat intercropped on April 27 (Table 2). Conversely, the correlation between the total number of arthropod pests and primary productivity was not significant in the cotton-wheat plots planted on April 27. Phytophage productivity correlated significantly with the primary assemblage in both inter-cropped cotton fields. No significant correlation existed between number or energy flow diversity indices for phytophages and productivity of the primary assemblage except energy flow diversity indices for phytophages in the cotton-wheat plots planted on May 15. Moreover, the diversity indices of energy flow diversity indices for phytophages exhibited a negative correlation with productivity of the primary assemblage in all agroecosystems.

\subsubsection{Structure index of predator assemblage and produc- tivity of the phytophage assemblage}

The species richness of predators depended on the productivity of the phytophage assemblage (Table 2). Significant correlations between species richness of the predator assemblage and phytophage productivity were found in all cotton agroecosystems except for cotton plots planted on April 27. There was a significant correlation $(P=0.0164)$ between the total individual number of predator assemblage and productivity of the phytophage assemblage in the intercropped cotton-wheat planted on April 27. There were no significant correlations between the productivity of predators and phytophages. Diversity indices of energy flow and number diversity indices of the predator assemblage were negatively correlated with the productivity of phytophage assemblage (but not significantly) in most cotton agroecosystems (Table 2).

\subsubsection{Structure index of parasitoid assemblage and productivity of the phytophage assemblage}

Correlation between the species richness of the parasitoid assemblage and phytophage productivity was significant $(P=0.0277)$ only in cotton plots planted on April 27. The total individual numbers of parasitoids and the phytophage assemblage productivity showed significant correlations in the cotton plots, except for those planted on April 27. The productivity of the parasitoid assemblage depended significantly on phytophage productivity. However, the diversity indices of energy flow and number diversity indices for parasitoids were not significantly correlated with productivity of phytophage assemblage in most cotton agroecosystems (Table 2).

\section{Discussion}

The existing literature contains conflicting evidence on the relationship between species diversity and productivity, and field experiments indicate both negative and positive correlations between productivity and species diversity [1,33]. Moreover, much of the evidence for the relationship biodiversity and productivity originates from plant-based studies at a single trophic level [1]. Here we assessed the correlation between productivity and diversity of phytophage and natural enemy assemblages associated with planting date and intercropping in four types of cotton agroecosystems. Our studies from four cotton agroecosystems showed that diversity indices of arthropod pest and natural enemy assemblages had no significant correlation with lower trophic assemblage productivity. In other words, arthropod diversity does not depend on host productivity in agroecosystems. 
Table 2 Correlations between the productivity of primary crop or phytophage assemblage and structure index of higher trophic level assemblage in four types of cotton agroecosystems $(\mathrm{d} f=20)^{\mathrm{a})}$

\begin{tabular}{|c|c|c|c|c|c|c|c|}
\hline Correlation mode & Seed time & Types of agroecosystem & $P-S$ & $P-N$ & $P-P$ & $P-H E$ & $P-H N$ \\
\hline \multirow{4}{*}{ Primary crop productivity-phytophage assemblages } & April 27 & Cotton & 0.359 & $0.597^{*}$ & 0.309 & -0.060 & 0.056 \\
\hline & April 27 & Cotton-wheat intercrop & $0.716^{* *}$ & 0.353 & $0.693^{* *}$ & -0.191 & -0.049 \\
\hline & May 15 & Cotton & -0.314 & $0.548^{*}$ & 0.091 & -0.005 & 0.131 \\
\hline & May 15 & Cotton-wheat intercrop & 0.336 & $0.536^{*}$ & $0.650^{* *}$ & -0.120 & $0.641^{*}$ \\
\hline \multirow{3}{*}{ Phytophage productivity-predator assemblages } & April 27 & Cotton & 0.244 & 0.271 & -0.080 & 0.321 & $0.452^{*}$ \\
\hline & April 27 & Cotton-wheat intercrop & $0.594^{* *}$ & $0.442^{*}$ & 0.271 & -0.258 & -0.284 \\
\hline & May 15 & Cotton-wheat intercrop & $0.494^{*}$ & 0.351 & 0.088 & -0.249 & -0.082 \\
\hline \multirow{4}{*}{ Phytophage productivity-parasitoid assemblages } & April 27 & Cotton & $0.500^{*}$ & 0.304 & $0.526^{*}$ & 0.429 & 0.301 \\
\hline & April 27 & Cotton-wheat intercrop & 0.130 & $0.464^{*}$ & $0.512^{*}$ & 0.332 & 0.319 \\
\hline & May 15 & Cotton & 0.427 & $0.795^{* *}$ & $0.816^{* *}$ & $0.442 *$ & 0.245 \\
\hline & May 15 & Cotton-wheat intercrop & 0.423 & $0.460^{*}$ & $0.609^{* *}$ & 0.007 & 0.189 \\
\hline
\end{tabular}

a) $P$, the productivity; $S$, species; $N$, total individual numbers; $H E$, diversity indices for assemblage energy flow; $H N$, diversity indices for assemblage numbers. ${ }^{*}$ and $* *$ indicate significant correlation at $P<0.05$ and $P<0.01$, respectively.

The diversity index of Shannon-Weaver [32] has been extensively used as a measure of assemblage diversity. All proposed functional diversity measures have assumed that individuals in a given assemblage are equally important, even if they make disproportionate contributions to assemblage function [34]. However, several studies have reported on how variation among individuals of the same species is important for assemblage function [35,36]. Up to this point, none of the methods proposed for estimating functional diversity [37] give a clear approach to incorporating information about individuals [34]. Our previous research deduced the diversity index of energy flow based on the Shannon-Wiener index by ecological energetics, as a measure of the functional diversity index, which includes measures that incorporate information about the abundance, age structure, life history, and mortality of each species in a assemblage [18]. In the current paper, we further found the diversity indices, including indices of energy flow diversity and numerical diversity, do not relate with their productivity or lower trophic assemblage productivity in most cotton fields for either the phytophage or the natural enemy assemblages.

The effects of arthropods on primary production may also be influenced by plant species diversity. This topic has been of interest to agro-ecologists who seek to understand why pest outbreaks are more frequent in monocultures than in polycultures [38]. Multiple-cropping practices influence resource concentration, and therefore, may affect density and productivity of pests and other organisms [39]. Experimental tests have been conducted mainly in agricultural ecosystems by comparing the number of herbivores and natural enemies in monocultures and polycultures from just the perspective of abundance $[22,40]$. However, reviews of the intercropping literature indicate that, relative to monocultures, herbivores in intercropping systems were less abundant in more than $50 \%$ of the studies, more abundant in 15 to $18 \%$, and variable in about $20 \%$ [38,41]. About $9 \%$ of the studies showed no difference in density between cropping systems [42]. In our study, lower productivity and assimilation of phytophages occurred in the inter-planted cotton fields compared to cotton monocultures. Productivity and assimilation of the natural enemy assemblages exhibited a complex pattern, but the results suggest that inter-cropped cotton fields had a stronger ability to support the natural enemy assemblage and reduce phytophages.

Studies conducted in Georgia [43] and Louisiana [44] demonstrated that maturity group and planting date can influence the seasonal abundance of arthropod pests of soybean, as well as of beneficial arthropods (arthropods and spiders). Additionally, the success of a trap crop strategy to manage certain arthropod pests depends on soybean maturity group, and planting date associated with early soybean production was the most important factors influencing arthropod densities [45]. Agi et al. [46] considered that early planting may be an effective management strategy for Bollgard cotton in North Carolina. However, Slosser et al. [25] believed that cotton bollworm larvae were not influenced significantly by planting date in irrigated and dryland cotton in the Texas Rolling Plains. In these studies, planting date significantly influenced productivity and assimilation of the phytophage assemblage in the mono cultured cotton plots, but no significant effects were found in the inter-cropped cotton plots. Furthermore, even higher trends were found in inter-cropped plots planted on May 15 than those planted on April 27. For both predator and parasitoid assemblages, planting date did not show any significant differences in the four cotton plots. These results suggest that late-planted mono cotton agroecosystems increased productivity of the phytophages and transformed the food into energy to support phytophage development better than early-planted mono cotton agroecosystems.

In conclusion, our results clearly showed that there was no correlation between productivity and diversity indices (including indices of energy flow diversity and number di- 
versity) in most cotton plots for phytophages and their predator assemblage. In the cotton-wheat agroecosystem, the higher species richness (e.g., intercropped cotton fields) can increase the assemblage utilization of light energy and, in turn, increase productivity for primary producers, which were more able to increase the productivity of the natural enemy assemblage and to control phytophages. On the other hand, planting date significantly influenced productivity and assimilation of the phytophage assemblage in the mono cultured cotton plots, but not for predator and parasitoid assemblages in the inter-cropped cotton plots. Consequently, we believe that inter-cropped agricultural manipulation appears optimal for natural enemies to control arthropod pests in northern China.

We are grateful to Dr. MK Harris and JE Slosser from Texas A\&M University for their constructive comments on earlier versions of the manuscript. This work was supported by the National Natural Science Foundation of China (31101491, 31030012) and National Key Technology R\&D Program (2012BAD19B05).

1 Hooper DU, Chapin FS, III Ewel JJ, Hector A, Inchausti P, Lavorel S, Lawton JH, Lodge DM, Loreau M, Naeem S. Effects of biodiversity on ecosystem functioning: a consensus of current knowledge. Ecolog Monogr, 2005, 75: 3-35

2 Duffy JE, Cardinale BJ, France KE, Mclntyre PB, Thcbbault E, Loreau $\mathrm{M}$. The functional role of biodiversity in ecosystems: incorporating trophic complexity. Ecol Lett, 2007, 10: 522-538

3 Tilman D, Wedin D, Knops J. Productivity and sustainability influenced by biodiversity in grassland ecosystems. Nature, 1996, 379: 718-720

4 Fornara DA, Tilman D. Ecological mechanisms associated with the positive diversity-productivity relationship in an $\mathrm{N}$-limited grassland. Ecology, 2009, 90: 408-418

5 Cardinale BJ, Matulich KL, Hooper DU, Bynes JE, Duffy E, Gamfeldt L, Balvanera P, O'Connor MI, Gonzalez A. The functional role of producer diversity in ecosystems. Am J Bot, 2011, 98: 572-592

6 Naeem S, Thompson LJ, Lawlor SP, Lawton JH, Woodfin RM. Declining biodiversity can alter the performance of ecosystems. Nature, 1994, 368: 734-737

7 Wardle DA, Bonner KI, Nicholson KS. Biodiversity and plant litter: experimental evidence which does not support the view that enhanced species richness improves ecosystem function. Oikos, 1997, 79: 247-258

8 Lawton JH, Naeem S, Thompson LJ, Hector A, Crawley MJ. Biodiversity and ecosystem function: getting the Ecotron experiment in its correct context. Funct Ecol, 1998, 12: 848-852

9 Mittelbach GG, Steiner CF, Scheiner SM Gross KL, Reynolds HL, Waide RB, Willig MR, Dodson SI, Gough L. What is the observed relationship between species richness and productivity? Ecology, 2001, 82: 2381-2396

10 Cornwell WK, Grubb PJ. Regional and local patterns in plant species richness with respect to resource availability. Oikos, 2003, 100: 417-428

11 Keddy P. Putting the plants back into plant ecology: six pragmatic models for understanding and conserving plant diversity. Ann Bot, 2005, 96: 177-189

12 Adler PB, Seabloom EW, Borer ET, Hillebrand H, Hautier Y, Hector A, Harpole WS, O’Halloran LR, Grace JB, Anderson TM, Bakker JD, Biederman LA, Brown CS, Buckley YM, Calabrese LB, Chu CJ, Cleland EE, Collins SL, Cottingham KL, Crawley MJ, Damschen EI, Davies KF, DeCrappeo NM, Fay PA, Firn J, Frater P. Productivity is a poor predictor of plant species richness. Science, 2011, 333:
$1750-1753$

13 Griffiths GJK, Wilby A, Crawley MJ, Thomas MB. Density-dependent effects of predator species-richness in diversity-function studies. Ecology, 2008, 89: 2986-2993

14 Chase JM, Leibold MA. Spatial scale dictates the productivity-biodiversity relationship. Nature, 2002, 416, 427-430

15 Naeem S. Ecosystem consequences of biodiversity loss: the evolution of a paradigm. Ecology, 2002, 83: 1537-1552

16 Tilman D, Reich PB, Knops J, Wedin D, Mielke T, Lehman C. Diversity and productivity in a long-term grassland experiment. Science, 2001, 294: 843-845

17 Relyea RA. The impact of insecticides and herbicides on the biodiversity and productivity of aquatic community. Ecol Appl, 2005, 15: 618-627

18 Gao F, Ge F, Liu XH, Song Y. Impact of insecticides on the structure and productivity of insect pest and natural enemy communities associated with intercropping in cotton agroecosystems. Int J Pest Manage, 2008, 54: 103-114

19 Cardinale BJ, Srivastava DS, Duffy JE, Wright JP, Downing AL, Sankaran M, Jouseau C. Effects of biodiversity on the functioning of trophic groups and ecosystems. Nature, 2006, 443: 989-992

20 Isbell FI, Polley WH, Wilsey BJ. Biodiversity, productivity and the temporal stability. Ecol Lett, 2009, 12: 443-451

21 Wenninger EJ, Inouye RS. Insect community response to plant diversity and productivity in a sagebrush-steppe ecosystem. J Arid Environ, 2008, 72: 24-33

22 Mensah RK. Habitat diversity: implications for the conservation and use of predatory insects of Helicoverpa spp. in cotton systems in Australia. Int J Pest Manage, 1999, 45: 91-100

23 Francis CA. Biological efficiencies in multiple-cropping systems. Adv Agron, 1989, 42, 1-42

24 Rummel DR, Carroll SC. Winter survival and effective emergence of boll weevil cohorts emtering winter habitat at different times. Southwest Entomol, 1983, 8: 101-106

25 Slosser JE, Bordovsky DG, Bevers SJ. Damage and costs associated with insect management options in irrigated cotton. J Econ Entomol, 1994, 87: 436-445

26 Ge F, Ding YQ. Functional features of preserving natural enemies to control insect pests in intercropped cotton field ecosystems. Chinese J Appl Ecol, 1997, 8: 295-298

27 Men X, Ge F, Yardim EN, Liu XH. Evaluation of winter wheat of as a potential crop enhancing biological control cotton aphids. Biocontrol, 2004, 49: 701-714

28 Hardee DD, Smith MT, Weathersbee AA. Sampling of the cotton aphid, Aphis gossypii Glover, in cotton. In: Proceedings of Beltwide Cotton Production and Research Conferences. National Cotton Council of America, Memphis, USA. 1993. 738-740

29 Weigert RG, Petersen CE. Energy transfer in insects. Ann Rev Entomol, 1983, 28, 455-486

30 McEvoy PB. Balancing insect energy budgets. Oecologia, 1985, 66, $154-156$

31 Thormley JHM, Hesketh JD. Growth and respiration in cotton bolls. J Appl Ecol, 1973, 6: 315-317

32 Shannon C, Weaver W, eds. The mathematical theory of communication. Urbana: University of Illinois Press, 1949. 117-118

33 Abramsky Z, Rosenzweig ML. Tilman's predicted productivity-diversity relationship shown by desert rodents. Lett Nature, 1984, 309: $150-151$

34 Cianciaruso MV, Batalha MA, Gaston KJ, Petchey OL. Including intraspecific variability in functional diversity. Ecology, 2009, 90: 81-89

35 Norberg J, Swaney DP, Dushoff J, Lin J, Casagrandi R, Levin SA. Phenotypic diversity and ecosystem functioning in changing environments: a theoretical framework. Proc Natl Acad Sci USA, 2001, 98: 11376-11381

36 Madritch MD, Hunter MD. Intraspecific litter diversity and nitrogen deposition affect nutrient dynamics and soil respiration. Oecologia, 2003, 136: 124-128

37 Petchey OL, Gaston KJ. Functional diversity: back to basics and 
looking forward. Ecol Lett, 2006, 9: 741-758

38 Andow DA. Vegetational diversity and arthropod population response. Ann Rev Entomol, 1991, 36: 561-586

39 Kareiva P. Influence of vegetation texture on herbivore populations: resource concentration and hervibvore movement. In: Denno RF, Mcclure MS, eds. Variable Plants and Herbivores in Natural and Managed Systems. New York: Academic Press, 1983. 259-289

40 Koricheva J, Mulder CPH, Schmid B, Joshi J, Huss-Danell K. Numerical responses of different trophic groups of invertebrates to manipulations of plant diversity in grasslands. Oecologia, 2000, 125: 271-282

41 Risch SJ, Andow D, Altieri MA. Agroecosystem diversity and pest control: data, tentative conclusions, and new research directions. Environ Entomol, 1983, 12, 625-629

42 Smith HA, McSorley R. Intercropping and pest management: a re- view of major concepts. Am Entomol, 2000, 46:154-161

43 McPherson RM, Layton RC, McLaurin WJ, Mills WA. Influence of irrigation and maturity group on the seasonal abundance of soybean arthropods. J Entomol Sci, 1998, 33: 378-392

44 Boyd ML, Boethel DJ, Leonard BR, Habetz RJ, Brown LP, Hallmark WB. Seasonal abundance of arthropod populations on selected soybean varieties grown in early season productivity systems in Louisiana. La Agric Exp Stn Bull, 1997, 860

45 Baur ME, Boethel DJ, Boyd ML, Bowers GR, Way MO, Heatherly LG, Rabb J, Ashlock L. Arthropod populations in early soybean production systems in the mid-South. Environ Entomol, 2000, 29: 312-328

46 Agi AL, Burd A, Bradley JR Jr, Duyn JW van. Planting date effects on heliothine larval numbers, fruit damage, and yield of transgenic $B t$ cotton in North Carolina. J Entomol Sci, 2001, 36: 402-410

Open Access This article is distributed under the terms of the Creative Commons Attribution License which permits any use, distribution, and reproduction in any medium, provided the original author(s) and source are credited. 